\title{
Body composition of goat kids during sucking. Voluntary feed intake
}

\author{
BY M. R. SANZ SAMPELAYO, I. RUIZ, F. GIL AND J. BOZA \\ Estación Experimental del Zaidin (Consejo Superior de Investigaciones Cientificas), Departamento \\ de Fisiologia Animal, Profesor Albareda, 1, 18008 Granada, Spain
}

(Received 8 December 1989 - Accepted 18 May 1990)

\begin{abstract}
The body composition of thirty-eight Granadina goat kids was measured. Six animals were slaughtered at birth while the remainder were kept individually at an environmental temperature of $24 \pm 2^{\circ}$ and a relative humidity of $60 \pm 5 \%$. They were given goat's milk or a milk-substitute at two planes of nutrition until 15 or $30 \mathrm{~d}$ of age and then slaughtered. The goat's milk and milk-substitute contained 260.4 and 222.0 $\mathrm{g}$ digestible protein/kg and $23 \cdot 23$ and $20.85 \mathrm{MJ}$ metabolizable energy/kg respectively. Voluntary feed intake as metabolizable energy was a function of metabolic body-weight $\left(\mathrm{kg} \mathrm{W}^{0.75}\right)$, equivalent to 2.42 and 2.44 times the energy requirement for maintenance for goat's milk- and milk-substitute-fed animals respectively. There was a high degree of correlation between the empty-body concentration of dry matter, fat and energy and empty-body-weight $(P<0.001)$ or animal age $(P<0.001)$, and between body-weight and animal age $(P<0.001)$. The relationships between empty-body composition and emptybody-weight were independent of type of milk or plane of nutrition. In contrast relationships between empty-body composition or empty-body-weight and animal age were affected by the type of milk and, over all, by the plane of nutrition. All these results show that in these animals any body-weight will have a similar composition, but it will be reached earlier or later depending on dietary regimen and always with the limitation of voluntary intake.
\end{abstract}

Goat kids: Sucking period: Body composition

Body composition of animals during sucking has been reviewed recently (Walker, 1986). It seems that during this period, body composition is more closely related to body-weight than to age (Fraga et al. 1978). It is known also, that if the voluntary intake of milk can be increased during early life, then the animal will not only grow more quickly, but will be fatter at any given body-weight (Campbell \& Dunkin, 1983; Spencer \& Hull, 1984). In spite of this, in the preruminant animal the relationship between body-weight and body composition appears to be unaffected by the plane of nutrition (Norton et al. 1970). This lack of response may be accounted for by the relatively lower voluntary feed intake of preruminant animals, so that no excess energy is available to be stored as fat (Walker, 1986).

The work reported here, provides information about the voluntary feed intake and body composition during the sucking period in goat kids in response to feeding goat's milk and a milk-substitute at two different planes of nutrition. These topics have not been examined previously in goats, but a typical characteristic of the goat species is its poor fattening capacity (Gall, 1982; Morand-Fehr et al. 1985).

\section{MATERIALS AND METHODS}

\section{Animals}

Thirty-eight male Granadina goat kids were used. They were removed from their dams at $2 \mathrm{~d}$ of age. Then an initial slaughter group of six animals were killed while the remaining 
thirty-two animals were fed up to their 15 th or 30th day of age and slaughtered on the following day.

\section{Plan of experiments}

The experiments were designed in a completely randomized $2 \times 2 \times 2$ block. Treatments consisted of two types of milk, two planes of nutrition and two ages of animal.

\section{Experimental procedure}

Animals were placed individually in metabolism cages in an environment maintained at a temperature of $24 \pm 2^{\circ}$ and a relative humidity of $60 \pm 5 \%$. They were given colostrum to appetite for $4 \mathrm{~d}$. Goat's milk or a milk-substitute was fed from day 5 to day 15 or day 30 . The two liquid diets were given to appetite and at $80 \%$ of that intake. These were the high $(\mathrm{H})$ and medium $(\mathrm{M})$ planes of nutrition respectively. Milk was given at 09.00 and 17.00 hours by bottle at $35^{\circ}$. The time of access to the milk was $2 \mathrm{~h}$. Milk-substitute was prepared at $170 \mathrm{~g} / \mathrm{kg}$ before feeding. The exact intakes were determined by weighing the bottles before and after sucking. The digestible protein $(\mathrm{g} / \mathrm{kg}$ dry matter) and metabolizable energy (MJ $/ \mathrm{kg}$ dry matter) contents of the goat's milk were 260.4 and 23.23 respectively and that of the milk-substitute 222.0 and 20.85 respectively. Animals were weighed every $3 \mathrm{~d}$. Each of eight animals consumed the natural or artificial milk at $\mathbf{H}$ or $\mathbf{M}$ planes of nutrition. Four of them were slaughtered at $16 \mathrm{~d}$ age and four at $31 \mathrm{~d}$ of age. Because of this, the kids were without food for $18 \mathrm{~h}$ before slaughter. The animals were anaesthetized by intramuscular injection of Xylazine (Rompun ${ }^{(\mathbb{B})}$, Bayer) before bleeding by aorta cannulation via the carotid artery. After slaughter, the different stomach compartments were emptied of digesta and the empty-body-weight measured. The empty-body was minced and a sample analysed for dry matter, protein, fat and energy.

\section{Analytical procedures}

Dry matter and nitrogen contents were determined in fresh samples. All other analyses were carried out on freeze-dried samples. Nitrogen contents were determined by Kjeldahl, energy contents in an adiabatic bomb calorimeter and fat contents by extraction with chloroform/methanol $(2: 1 \mathrm{v} / \mathrm{v})$.

\section{Statistical analysis}

The results of the experiments were statistically analysed by means of standard regression techniques.

\section{RESULTS}

\section{Voluntary feed intake}

Intake is often assumed to be a function of metabolic weight and feeding scales are frequently expressed as a fixed multiple of energy maintenance requirement. So, the relationship between intake of milk metabolizable energy $(\mathrm{kJ} / \mathrm{d})$ and metabolic bodyweight $\left(\mathrm{kg} / \mathrm{W}^{0 \cdot 75}\right)$ was determined for animals fed on goat's milk and milk-substitute at the $\mathrm{H}$ plane of nutrition. All available values from 5 to $30 \mathrm{~d}$ were used. These relationships may be described by the following linear equations:

$$
\begin{aligned}
& \text { goat's milk: } \quad y=-313.0(\mathrm{SE} 134 \cdot 1)+1181 \cdot 4(\mathrm{SE} 191 \cdot 1) x(r 0 \cdot 86), \\
& \text { milk-substitute: } y=-271 \cdot 3(\mathrm{SE} 88 \cdot 5)+1099 \cdot 1(\mathrm{SE} 177 \cdot 3) \times(r 0 \cdot 86) .
\end{aligned}
$$

Where $y$ is milk energy intake ( $\mathrm{kJ} \mathrm{ME} / \mathrm{d}$ ) and $x$ is $\mathrm{W}^{0.75}(\mathrm{~kg})$. Neither the intercept term nor the regression coefficients were significantly different, so a combined equation was calculated. All values: $y=-333.9($ SE 101.0) +1154.9 (SE 134.8) $x(r$ 0.86). The regressions 
Table 1. Empty-body-weight and empty-body composition in the Granadina goat kid

\begin{tabular}{|c|c|c|c|c|c|c|c|c|c|c|c|c|}
\hline \multirow[b]{2}{*}{ Age (d) } & \multicolumn{2}{|c|}{ Feeding } & \multicolumn{2}{|c|}{$\begin{array}{c}\text { Empty-body-wt } \\
(\mathrm{kg})\end{array}$} & \multicolumn{2}{|c|}{$\begin{array}{c}\text { Dry matter } \\
(\mathrm{g} / \mathrm{kg})\end{array}$} & \multicolumn{2}{|c|}{$\begin{array}{l}\text { Protein } \\
(\mathrm{g} / \mathrm{kg})\end{array}$} & \multicolumn{2}{|c|}{$\begin{array}{c}\text { Fat } \\
(\mathrm{g} / \mathrm{kg})\end{array}$} & \multicolumn{2}{|c|}{$\begin{array}{l}\text { Energy } \\
(\mathrm{MJ} / \mathrm{kg})\end{array}$} \\
\hline & Type of milk & Plane of nutrition & Mean & $\mathrm{SE}$ & Mean & $\mathbf{S E}$ & Mean & SE & Mean & $\mathrm{SE}$ & Mean & SE \\
\hline 2 & - & - & $2 \cdot 11$ & $0 \cdot 10$ & $221 \cdot 9$ & 6.4 & $144 \cdot 3$ & $2 \cdot 4$ & $29 \cdot 4$ & $2 \cdot 5$ & $4 \cdot 61$ & $0 \cdot 13$ \\
\hline \multirow[t]{4}{*}{15} & \multirow[t]{2}{*}{ Goat milk } & High & $3 \cdot 93$ & $0 \cdot 10$ & $267 \cdot 9$ & $13 \cdot 1$ & $141 \cdot 6$ & $2 \cdot 2$ & $84 \cdot 6$ & $13 \cdot 9$ & 6.75 & 0.59 \\
\hline & & Medium & $3 \cdot 27$ & 0.22 & 241.9 & $12 \cdot 6$ & $144 \cdot 0$ & $3 \cdot 4$ & $55 \cdot 7$ & $8 \cdot 7$ & $5 \cdot 66$ & 0.42 \\
\hline & \multirow[t]{2}{*}{ Milk-substitute } & High & $3 \cdot 39$ & $0 \cdot 17$ & $228 \cdot 7$ & $10 \cdot 6$ & $146 \cdot 1$ & 3.9 & $72 \cdot 7$ & $10 \cdot 4$ & 5.91 & 0.56 \\
\hline & & Medium & 3.06 & 0.19 & $233 \cdot 4$ & 6.5 & $144 \cdot 7$ & $0 \cdot 2$ & $59 \cdot 2$ & $8 \cdot 6$ & $5 \cdot 12$ & $0 \cdot 35$ \\
\hline \multirow[t]{4}{*}{30} & \multirow[t]{2}{*}{ Goat milk } & High & 6.61 & $0 \cdot 26$ & $292 \cdot 8$ & $4 \cdot 0$ & $143 \cdot 0$ & $5 \cdot 6$ & 112.9 & $4 \cdot 5$ & 7.91 & 0.04 \\
\hline & & Medium & $4 \cdot 14$ & 0.90 & $267 \cdot 1$ & $17 \cdot 2$ & $148 \cdot 6$ & $8 \cdot 8$ & $80 \cdot 2$ & $3 \cdot 7$ & 674 & $0 \cdot 35$ \\
\hline & \multirow[t]{2}{*}{ Milk-substitute } & High & $5 \cdot 36$ & $0 \cdot 30$ & $282 \cdot 5$ & $5 \cdot 6$ & $147 \cdot 7$ & $1 \cdot 1$ & $97 \cdot 0$ & $0 \cdot 2$ & $7 \cdot 39$ & 0.03 \\
\hline & & Medium & 4.49 & $0 \cdot 31$ & $274 \cdot 2$ & $10 \cdot 9$ & $153 \cdot 7$ & 3.9 & $80 \cdot 4$ & $10 \cdot 0$ & $6 \cdot 87$ & $0 \cdot 32$ \\
\hline
\end{tabular}

covered the range of metabolizable energy intake from 1507 to $5231 \mathrm{~kJ} / \mathrm{d}$ and of $\mathrm{W}^{0.75}$ from 1.55 to $4.28 \mathrm{~kg}$. From the mean values for energy intake and $W^{0.75}$ and from the energy requirements for maintenance for this kind of animal (Sanz Sampelayo et al. 1988), it was possible to calculate the voluntary feed intake as multiples of those requirements, i.e. 2.42 and 2.44 for kids fed on goat's milk and milk-substitute respectively.

Relationship between empty-body composition and empty-body-weight or animal age The regression of concentration of different empty-body components $(\mathrm{g} / \mathrm{kg}$ or $\mathrm{MJ} / \mathrm{kg} ; y)$; $v$. empty-body-weight or animal-age values ( $\mathrm{kg}$ or $\mathrm{d}$ respectively; $x$ ), used an allometric equation of the type: $\log y=a+b \log x$. Likewise, the relationship between empty-bodyweight $(\mathrm{kg}, y)$ and animal age $(\mathrm{d} ; x)$ was also calculated. The individual values were those obtained for animals slaughtered at birth and at 16 and $31 \mathrm{~d}$ of age (for mean values see Table 1). The use of this model to describe the relationship between body composition and body-weight or animal age is in agreement with Agricultural Research Council recommendations (1980). The sources of variation considered were the different dietary regimens: goat's milk or milk-substitute, each at the $\mathrm{H}$ and $\mathrm{M}$ plane of nutrition. There was no significant relationship between the concentration of protein and empty-body-weight or animal age $(P>0.05)$. There was a strong correlation between dry matter, fat or energy concentration and empty-body-weight $(P<0.001)$. As the latter relationships were not affected by type of milk and plane of nutrition, only one equation for each fraction was obtained (Table 2). There was also, a strong correlation between dry matter, fat, energy concentration or empty-body-weight and animal age $(P<0.001)$ (Table 3$)$. In all these instances, the different coefficients of regressions were significant $(P<0.05)$. From all these results, it can be concluded that when goat kids are restricted to particular dietary regimen, their empty-body composition is closely related to empty-body-weight and age. At the same time, the empty-body-weight reached in any case depends on age. It is interesting to note that the relationship between empty-body composition and empty-body-weight seems to be independent of type of milk and plane of nutrition. In contrast the relationships between empty-body composition or empty-body-weight and age appear to be affected by the type of milk and, over all, by the plane of nutrition. These aspects together with the fact that there were only minimal changes in the concentration of protein are illustrated in Figs 1 and 2. 
Table 2. Regression coefficients for relations between empty-body-weight and empty-body composition of goat kids

(Mean values with their standard errors for each fraction. Regression equation: $\log y=a+b \log x$, where $y$ is the dry matter, fat or energy concentration and $x$ is empty-body-weight $(\mathrm{kg}))^{*}$

\begin{tabular}{|c|c|c|c|c|c|c|}
\hline \multirow[b]{2}{*}{$y$} & \multicolumn{2}{|c|}{$a$} & \multicolumn{2}{|c|}{$b$} & \multirow[b]{2}{*}{$r$} & \multirow[b]{2}{*}{$\mathrm{RCV}(\%)$} \\
\hline & Mean & $\mathrm{SE}$ & Mean & SE & & \\
\hline Dry matter $(\mathrm{g} / \mathrm{kg})$ & $5 \cdot 18$ & $0 \cdot 020$ & $0 \cdot 28$ & 0.029 & 0.920 & 0.79 \\
\hline Fat $(\mathrm{g} / \mathrm{kg})$ & $2 \cdot 66$ & $0 \cdot 164$ & $1 \cdot 17$ & $0 \cdot 116$ & 0.927 & $4 \cdot 24$ \\
\hline Energy $(\mathrm{MJ} / \mathrm{kg})$ & $1 \cdot 14$ & 0.088 & 0.51 & 0.037 & 0.958 & $3 \cdot 17$ \\
\hline
\end{tabular}

$\mathrm{RCV}$, residual coefficient of variation.

* For details, see p. 613 .

Table 3. Regression coefficients for relationships between age and empty-body-weight $(E B W)$ and empty-body composition of goat kids

(Mean values with their standard errors for each of the four dietary regimens: goat milk (GM) at high (H) and medium (M) planes of nutrition and milk-substitute (MS) at $\mathrm{H}$ and $\mathrm{M}$ planes of nutrition. Regression equation: $\log y=a+b \log x$, where $y$ is the $\mathrm{EBW}$ or the dry matter, fat or energy concentrations in EBW and $x$ is animal age (d))*

\begin{tabular}{|c|c|c|c|c|c|c|}
\hline \multirow[b]{2}{*}{$y$} & \multicolumn{2}{|c|}{$a$} & \multicolumn{2}{|c|}{$b$} & \multirow[b]{2}{*}{$r$} & \multirow[b]{2}{*}{$\operatorname{RCV}(\%)$} \\
\hline & Mean & $\mathrm{SE}$ & Mean & $\mathrm{SE}$ & & \\
\hline \multicolumn{7}{|l|}{ EBW $(\mathrm{kg})$} \\
\hline GM: H & $0 \cdot 39$ & $0 \cdot 033$ & $0 \cdot 41^{\mathrm{a}}$ & 0.017 & 0.962 & $5 \cdot 11$ \\
\hline $\mathrm{M}$ & 0.47 & 0.032 & $0 \cdot 31^{\mathrm{h}}$ & 0.016 & 0.940 & 5.68 \\
\hline MS: $\mathbf{H}$ & 0.45 & 0.031 & $0.33^{b}$ & 0.016 & 0.951 & $5 \cdot 29$ \\
\hline $\mathrm{M}$ & 0.50 & 0.032 & $0 \cdot 27^{5}$ & 0.016 & 0.926 & 5.87 \\
\hline \multicolumn{7}{|c|}{ Dry matter $(\mathrm{g} / \mathrm{kg})$} \\
\hline GM: $\mathrm{H}$ & 5.33 & 0.010 & $0 \cdot 10^{\mathrm{a}}$ & 0.003 & 0.947 & 0.79 \\
\hline $\mathrm{M}$ & $5 \cdot 34$ & $0 \cdot 017$ & $0.07^{b}$ & 0.008 & 0.744 & $1 \cdot 36$ \\
\hline MS: ${ }^{M}$ & $5 \cdot 30$ & 0.023 & $0.08^{\mathrm{b}}$ & $0 \cdot 012$ & 0.713 & 1.87 \\
\hline $\mathrm{M}$ & 5.32 & $0-018$ & $0.07^{\mathrm{b}}$ & 0.009 & 0.765 & 1.42 \\
\hline \multicolumn{7}{|l|}{ Fat $(\mathrm{g} / \mathrm{kg})$} \\
\hline \multirow{2}{*}{ GM: $\mathrm{H}$} & 3.05 & $0 \cdot 064$ & $0 \cdot 50^{\mathrm{a}}$ & $0 \cdot 016$ & 0.976 & $3 \cdot 26$ \\
\hline & 3.09 & $0-069$ & $0 \cdot 36^{\mathrm{b}}$ & 0.017 & 0.950 & 3.79 \\
\hline \multirow{2}{*}{ MS: $\frac{\mathrm{H}}{\mathrm{M}}$} & 3.08 & 0.005 & $0 \cdot 44^{c}$ & 0.001 & 0.999 & 0.26 \\
\hline & $3 \cdot 11$ & 0.072 & $0 \cdot 37^{b}$ & 0.018 & 0.947 & 3.94 \\
\hline \multicolumn{7}{|l|}{ Energy $(\mathrm{MJ} / \mathrm{kg})$} \\
\hline \multirow{2}{*}{ GM: } & $1 \cdot 38$ & $0 \cdot 034$ & $0 \cdot 20^{\mathrm{a}}$ & 0.007 & 0.959 & 3.96 \\
\hline & 1.41 & 0.041 & $0 \cdot 14^{\mathrm{b}}$ & $0 \cdot 010$ & 0.887 & $5 \cdot 17$ \\
\hline MS: $\mathrm{H}$ & 1.38 & 0.029 & $0.17^{\circ}$ & 0.010 & 0.959 & 3.52 \\
\hline $\mathrm{M}$ & 1.37 & $0 \cdot 063$ & $0 \cdot 14^{b}$ & 0.012 & 0.782 & $8 \cdot 10$ \\
\hline
\end{tabular}

\&, b,c mean values with different superscript letter were significantly different: $P<0.05$.

$\mathrm{RCV}$, residual coefficient of variation.

* For details, see p. 613.

\section{DISCUSSION \\ Voluntary feed intake}

The feed that can be ingested by a particular animal during its growing period is an important factor determining its growth rate. The voluntary feed intake of an animal is probably associated with its intake capacity and with its energy requirement for 

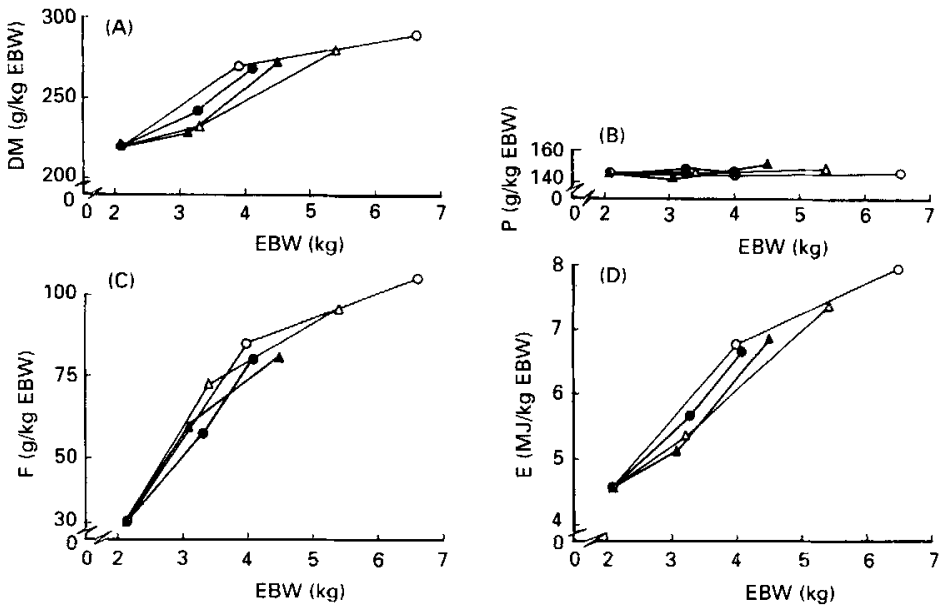

Fig. 1. Empty-body-weight (EBW) composition of goat kids in relation to EBW values: (A) dry matter (DM), (B) protein, (C) fat and (D) energy concentrations. Animals fed with goat milk (260.4 g digestible protein $/ \mathrm{kg} \mathrm{DM}$ and $23.23 \mathrm{MJ}$ metabolizable energy $/ \mathrm{kg} \mathrm{DM})$ or a milk-substitute $(222.0 \mathrm{~g}$ digestible protein $/ \mathrm{kg} \mathrm{DM}$ and $20.85 \mathrm{MJ}$ metabolizable energy $/ \mathrm{kg} \mathrm{DM})$ to appetite $(O, \triangle)$ and at $80 \%$ of that $(\boldsymbol{O}, \Delta)$ respectively.
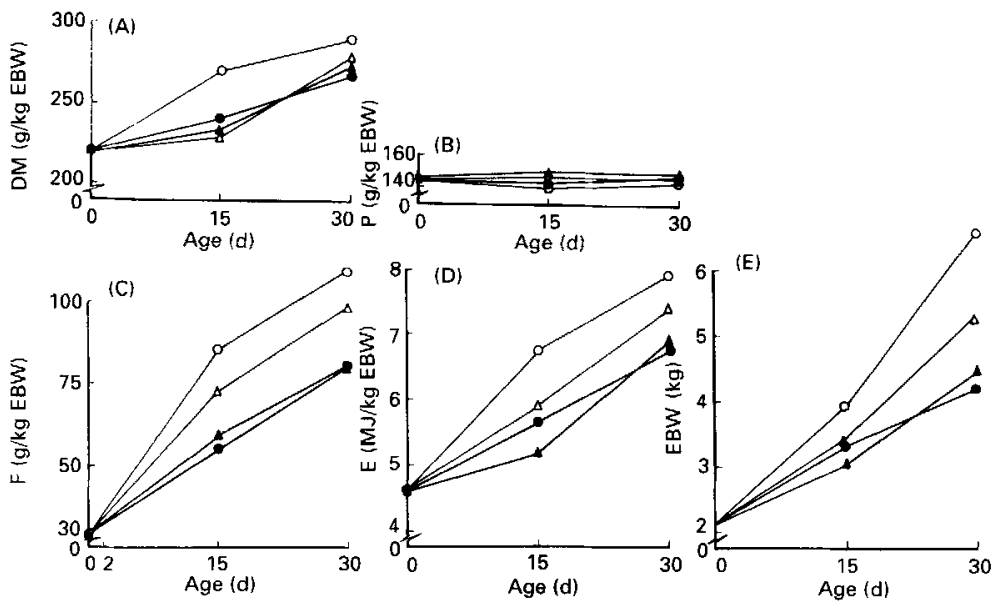

Fig. 2. Empty-body-weight (EBW) composition and EBW values of goat kids in relation to animal age. (A) dry matter (DM), (B) protein, (C) fat and (D) energy concentrations and (E) EBW values. Animals fed with goat milk $(260.4 \mathrm{~g}$ digestible protein $/ \mathrm{kg} \mathrm{DM}$ and $23.23 \mathrm{MJ}$ metabolizable energy $/ \mathrm{kg} \mathrm{DM})$ or a milk-substitute $(222.0 \mathrm{~g}$ digestible protein $/ \mathrm{kg} \mathrm{DM}$ and $20.85 \mathrm{MJ}$ metabolizable energy $/ \mathrm{kg} \mathrm{DM})$ to appetite $(\mathrm{O}, \triangle)$ and at $80 \%$ of that $(\boldsymbol{O}, \mathbf{\Delta})$ respectively.

maintenance (Hodge, 1974). As far as preruminant animals are concerned, it seems that in the first days of life, abomasal development could be the first factor regulating their maximum feed intake. Thereafter, at 2-4 weeks of age maximum intake starts to be efficiently regulated by energy requirements (Ternouth et al. 1985; Bas, 1988). In respect of the energy requirement for maintenance, the values estimated for goat kids given goat's milk or milk-substitute, 470 (Jagusch et al. 1983) and $429 \mathrm{~kJ} \mathrm{ME} / \mathrm{kg} \mathrm{W}^{0.75}$ per d (Sanz Sampelayo et al. 1988) are similar to estimates for lambs, 465 (Walker \& Norton, 1970) and young calves, $452 \mathrm{~kJ} \mathrm{ME} / \mathrm{kg} \mathrm{W}^{0 \cdot 75}$ per d (Vermorel, 1979) fed on milk or milk-substitute. Hodge (1974) reported on voluntary feed intake in sucking lambs and pigs. The value for pigs exceeded that for lambs by over $50 \%$ and was associated with a higher maintenance 
requirement and a higher relative feed capacity. The value calculated for lambs was equal to 3.63 times its maintenance requirement value, rather higher than the value of 2.4 found here for goat kids.

\section{Body composition of the newborn}

At birth the concentration of protein and fat is generally higher and that of water lower with higher live weights. Therefore, there is an appreciable change in the protein; water ratio with increasing birth weight (Agricultural Research Council, 1980). For animals with similar weights at birth the differences in fat concentration may reflect differences in fattening capability and, at the same time, may be partly determined by maternal nutrition (Agricultural Research Council, 1980). Jagusch et al. (1983) reported findings for the empty-body-weight at birth and its composition for male Saanen goat kids. The mean empty-body-weight was higher than that found here for Granadina goats (3.99 v. $2 \cdot 11 \mathrm{~kg})$. The differences in the concentrations of water $(739.2 v .778 \cdot 1 \mathrm{~g} / \mathrm{kg})$ and protein $(189.8 v$ $144.3 \mathrm{~g} / \mathrm{kg}$ ) between the breeds were in accord with the differences in body weight at birth, but the quantity of fat was rather higher for the Granadina kids $(24.3 v .29 .4 \mathrm{~g} / \mathrm{kg})$ which may be because Granadina kids have a higher fattening capability (Sanz Sampelayo et al. 1987). The Agricultural Research Council (1980) have reported representative values for the body-weight composition at birth lambs and calves; the effects of body-weight at birth on the values for water, protein, fat and energy concentration are in accord with those found here for goat kids.

\section{Body composition during sucking}

Body composition in growing animals depends on growth rate and the composition of any weight gain. At the same time, these two factors depend on diet, age, weight and genetic potential (Agricultural Research Council, 1980). The changes in the composition of the body during sucking have been discussed by Vermorel (1975) for preruminant lambs and calves, and recently by Walker (1986) for non-ruminant and ruminant species. Vermorel (1975) reported that when the animal grows, the protein of the new growth increments changes very little. In contrast, fat content increases and, in an inverse relationship, the proportion of water decreases. The results obtained here for the changes in the empty-body composition of the goat kid during its first month of life are in close agreement with these findings. With both types of milk and at both planes of nutrition, dry matter, fat and energy concentrations of empty-body were higher with greater empty-body-weight or animal age. Walker (1986) reported that when preruminant animals are restricted to a particular diet, their body composition is more closely related to body-weight than to age. At the same time, he discussed results from different experiments showing that in preruminant animals, the relationship between body-weight and body composition appears to be unaffected by the plane of nutrition. He explained this lack of response by taking into account the relatively lower voluntary feed intake of preruminant animals, implying that no excess energy is available to be stored as fat (Walker, 1986). Our results for the relationships between empty-body-weight or animal age and empty-body-weight composition, support these conclusions. Independently of dietary regimen, empty-body composition depends on empty-body-weight. However, any particular body-weight will be reached earlier or later depending on that dietary regimen and always with the limitation of voluntary feed intake. This emphasizes the importance of identifying those factors which, at nutritional and even physiological level, determine voluntary intake.

Financial support from LUCDEME (Lucha Contra la Desertificación del Mediterráneo) Program. 


\section{REFERENCES}

Agricultural Research Council (1980). The Nutrient Requirements of Ruminant Livestock. Slough: Commonwealth Agricultural Bureaux.

Bas, P. (1988). Influence of weaning age on growth, body composition and lipid metabolism of Alpine male kids. $\mathrm{PhD}$. Thesis, University of Paris.

Campbell, R. G. \& Dunkin, A. C. (1983). The effects of energy intake and dietary protein on nitrogen retention, growth performance, body composition and some aspects of energy metabolism of baby pigs. British Journal of Nutrition 49, 221-230.

Fraga, M. J., Torres, A., Pérez, E., Galvez, J. F. \& De Blas, J. C. (1978). Body composition in suckling rabbits. Journal of Animal Science 47, 166-175.

Gall, C. (1982). Carcass composition. Proceedings of the Third International Conference on Goat Production and Disease pp. 472-487. Tucson: Dairy Goat Journal Publishing Co.

Hodge, R. W. (1974), Efficiency of food conversion and body composition of the preruminant lamb and the young pig. British Journal of Nutrition 32, 113-126.

Jagusch, K. T., Duganzich, D. M., Kido, G. T. \& Church, S. M. (1983). Efficiency of goat milk utilisation by milkfed kids. New Zealand Journal of Agricultural Research 26, 443-445.

Morand-Fehr, P., Rouzeau, A. \& Hervieu, J. (1985). Development of characteristics of adipose deposits in male kids during growth from birth to weaning. Animal Production 41, 349-357.

Norton, B. W., Jagusch, K. T. \& Walker, D. M. (1970). Body composition studies with the milk fed lamb. III. The effect of the protein and energy intake on the composition of the live weight gain. Journal of Agricultural Science, Cambridge 75, 287-292.

Sanz Sampelayo, M. R., Muñoz, F. J., Lara, L., Gil Extremera, F. \& Boza, J. (1987). Factors affecting pre- and post-weaning growth and body composition in kid goats of the Granadina breed. Animal Production 45, $233-238$

Sanz Sampelayo, M. R., Muñoz, F. J., Guerrero, J. E., Gil Extremera, F. \& Boza, J. (1988). Energy metabolism of the Granadina breed goat kid. Use of goat milk and a milk replacer. Journal of Animal Physiology and Animal Nutrition 59, 1-9.

Spencer, S. A. \& Hull, D. (1984). The effect of over-feeding of newborn rabbits on somatic and visceral growth, body composition and long-term growth potential. British Journal of Nutrition 51, 389-402.

Ternouth, J. H., Stobo, I. J. F., Roy, J. H. B. \& Beattie, A. W. (1985). The effect of milk substitute concentration upon the intake, digestion and growth of calves. Animal Production 41, 151-159.

Vermorel, M. (1975). Le métabolisme énergétique du veau et de l'agneau préruminants. Les industries de TAlimentation Animale 1, 9-26.

Vermorel, M., Bouvier, J. C. \& Geay, Y. (1979). Energy utilization by growing calves: effects of age, milk intake and feeding level. In Energy Metabolism, pp. 49-53 (L. E. Mount, editor). London: Butterworths.

Walker, D. M. (1986) Body composition of animals during sucking and the immediate post-weaning period. Proceedings of the Nutrition Society 45, 81-89.

Walker, D. M. \& Norton, B. N. (1970). The utilization of energy by the milk-fed lamb. In Energy Metabolism, pp. 125-128 (A. Schurch and C. Wenk, editors), Zürich : Juris Orion-Verlag. 